Jurnal Akuntansi dan Bisnis: Jurnal Program studi Akuntansi, 5 (1) Mei 2019.

ISSN 2443-3071 (Print) ISSN 2503-0337 (Online). DOI: 10.31289/iab.v5i1.1837

JURNAL AKUNTANSI DAN BISNIS

Jurnal Program Studi Akuntansi

Available online http://ojs.uma.ac.id/index.php/jurnalakundanbisnis

\title{
FAKTOR-FAKTOR PELAPORAN KEUANGAN BERBASIS WEBSITE DENGAN MODEL REGRESI LOGISTIK
}

\author{
Wenny Anggeresia Ginting $a^{*}$, Munawarah ${ }^{a}$, Siti Dini ${ }^{a}$ \\ Universitas Prima Indonesia
}

Diterima September 2018; Disetujui Februari 2019; Dipublikasikan Mei 2019

\begin{abstract}
Abstrak
Penelitian ini memperlihatkan bukti empiris apakah terdapat pengaruh atas ukuran perusahaan, profitabilitas, dan reputasi auditor terhadap pengungkapan pelaporan keuangan berbasis website dan juga yang tidak berbasis website perusahaan tahun 2016. Penelitian ini menggunakan data seluruh perusahaan non keuangan yang terdaftar dalam Bursa Efek Indonesia (BEI) tahun 2016. Pengujian data penelitian menggunakan analisis regresi logistik. Hasil penelitian menunjukkan bahwa secara parsial variabel profitabilitas, tipe perusahaan, dan reputasi auditor berpengaruh dan signifikan terhadap IFR (Internet Financial Reporting), sedangkan variabel ukuran perusahaan tidak berpengaruh pada perusahaan non keuangan yang terdaftar di Bursa Efek Indonesia. Peluang untuk perusahaan non keuangan yang menerapkan IFR lebih besar daripada perusahaan-perusahaan yang tidak menerapkan IFR, alasan ini mendukung bahwa keberadaan internet melalui IFR telah banyak dimanfaatkan guna memperluas jaringan bisnis dalam setiap entitas bisnis melalui website perusahaan dibanding perusahaan yang belum menerapkannya.
\end{abstract}

Kata Kunci : laporan keuangan terintegrasi internet, Regresi Logistik, Bursa Efek Indonesia.

\begin{abstract}
This study shows the empirical evidence whether there are influences on company size, profitability, and auditor reputation on the disclosure of website-based financial reporting and also those not based on company websites in 2016. This study uses data from all non-financial companies listed on the Indonesia Stock Exchange (IDX) 2016. The testing of research data using logistic regression analysis. The results showed that partially the profitability variable, type of company, and auditor reputation had significant and significant effect on IFR (Internet Financial Reporting), while the firm size variable did not affect nonfinancial companies listed on the Indonesia Stock Exchange. Opportunities for non-financial companies that implement IFR are greater than companies that do not implement IFR, this reason supports that the existence of the internet through IFR has been widely used to expand business networks in each business entity through the company's website compared to companies that have not implemented it.

Keyword: integrated internet financial report, Logistic Regression, Indonesia Stock Exchange.
\end{abstract}

How To Cite: Ginting, et.al, (2019) Faktor-Faktor Pelaporan Keuangan Berbasis Website Dengan Model Regresi Logistik. Jurnal Akuntansi dan Bisnis: Jurnal Program Studi Akuntansi, 5 (1): 1-8

* email: gintinganggresiawenny@gmail.com

\section{PENDAHULUAN}

Internet merupakan salah satu sarana perkembangan terbesar di bidang teknologi informasi. Kehadiran internet di era globalisasi ini dapat membantu menghubungkan 
para penggunanya dari berbagai wilayah di seluruh dunia. (Hartanto, H. 2018). Perkembangan internet di Indonesia saat ini juga terjadi sangat pesat, ini dibuktikan dengan banyaknya jumlah pengguna internet di Indonesia yang terjadi di tahun 2016 yang mendudukkan Indonesia di peringkat ke-6 terbesar di dunia dalam jumlah penggunan internet yang membawahi beberapa negara lain seperti Rusia, Mexico dan Nigeria (Azizah \& Hutagalung, 2018). Perkembangan yang cepat dalam dunia internet tersebut membawa perubahan terhadap penyebaran informasi yang mempengaruhi baik secara langsung maupun tidak langsung pada dunia usaha. Dengan demikian, untuk dapat lebih bersaing perusahaan dihadapkan pada kondisi untuk dapat lebih transparan dalam mengungkapkan informasi perusahaannya, sehingga akan lebih membantu para pengambil keputusan dalam mengantisipasi kondisi yang semakin berubah. Linda (2012) menjustifikasi bahwa semakin besar suatu usaha bisnis, maka semakin tinggi perlunya informasi akuntansi, baik untuk pertanggungjawaban maupun untuk dasar pengambilan keputusan ekonomi.

Dalam penelitian ini, adapun upaya yang dapat dilakukan perusahaan guna mendukung informasi dalam dunia digital internet tersebut diatas adalah dengan membangun website company. Website adalah kumpulan halaman yang digunakan untuk menampilkan informasi, gambar, gerak dan suara atau gabungan semuanya yang membentuk suatu rangkaian bangunan saling terkait dimana masing-masing dihubungkan dengan link (Keumala, 2013). Awalnya website digunakan untuk memasarkan produk perusahaan, namun saat ini website juga dimanfaatkan sebagai media komunikasi dengan pihak-pihak yang terkait dengan perusahaan, baik dengan shareholders, stakeholders, maupun pihak lain yang berkepentingan khususnya investor, salah satunya dalam penyebaran informasi keuangan perusahaan (Hasugian, P. S. 2018).

Ukuran perusahaan merupakan salah satu faktor yang dapat mempengaruhi praktek IFR karena perusahaan yang lebih besar memiliki tingkat kompleksitas tinggi sehingga investor akan membutuhkan informasi keuangan yang lebih banyak untuk membuat keputusan investasi yang lebih efektif. Perusahaan besar memiliki agency cost yang besar karena perusahaan besar harus menyampaikan pelaporan keuangan yang lengkap kepada shareholders sebagai wujud pertanggungjawaban manajemen (Rohmah, A. N., \& Priantinah, D. 2018). Demikian halnya dengan reputasi auditor dimana untuk mempertahankan reputasinya Kantor Akuntan Publik (KAP) harus menjaga tingkat independensinya, sehingga mereka berusaha melaporkan informasi selengkap mungkin kepada pemegang saham dan pihak-pihak berkepentingan lainnya (Prastiwi, P. I., Astuti, D. S. P., \& Harimurti, F. 2019).

Tujuan penelitian ini adalah untuk untuk memberikan bukti empiris apakah terdapat pengaruh secara parsial dan simultan ukuran perusahaan, profitabilitas, dan reputasi auditor terhadap pengungkapan pelaporan keuangan berbasis website perusahaan tahun 2016 dan membandingkan seberapa besar peluang dalam hal mengungkapkan laporan keuangan yang dilakukan perusahaan dalam website perusahaan dengan yang tidak mengungkapkan laporan keuangan dalam website perusahaan tahun 2016.

Berdasarkan pada uraian latar belakang di atas, maka rumusan masalah yang dalam penelitian ini untuk melihat apakah terdapat pengaruh secara parsial dan simultan ukuran perusahaan, profitabilitas, dan reputasi auditor terhadap pelaporan keuangan berbasis website perusahaan tahun 2016. Selanjutnya permasalahan penelitian dalam mengetahui probabilitas perusahaan-perusahaan yang mengungkapkan laporan 
keuangan dalam website perusahaan dengan perusahaan yang tidak mengungkapkan laporan keuangan dalam website perusahaan tahun 2016

\section{METODE PENELITIAN}

Metode penelitian yang digunakan dalam penelitian ini adalah pendekatan kuantitatif. Menurut Kuncoro (2011), metode kuantitatif adalah pendekatan ilmiah terhadap pengambilan keputusan manajerial dan ekonomi. Metode pengumpulan data yang dilakukan dalam penelitian ini adalah metode tidak langsung (indirect method) yaitu dokumentasi melalui pencatatan atau mendownload data dari Bank Efek Indonesia (BEI). Jenis data yang digunakan dalam penelitian ini adalah data sekunder yang bersumber dari website resmi www.idx.co.idyang berbentuk data antara perusahaan dalam satu tahun atau runtun waktu (cross section), yaitu data periode 2016.

Populasi dalam penelitian ini adalah perusahaan non keuangan yang terdaftar di Bursa Efek Indonesia (BEI) pada tahun 2016 sebanyak 246 perusahaan. Dari 246 dipih 71 perusahaan sebagai sampel dalam penelitian ini dengan menggunakan formula Babbie (Hanny, 2012) yang terdiri dari pertanian, peternakan, pertambangan, jasa, manufaktur, perdagangan, properti dan real estate, dan lain-lain. Ukuran sampel dilakukan dengan menggunakan formula Babbie (Hanny, 2012) yaitu sebagai berikut:

N.pq

$$
n=\frac{}{(N-1) \frac{B^{2}+p q}{4}}
$$

Dimana:

$\mathrm{n} \quad$ = Jumlah sampel yang diinginkan

$\mathrm{N}=$ Populasi.

$\mathrm{P}=$ Nilai probabilitas $=0,5$ untuk meminimumkan risiko sampling.

$\mathrm{q} \quad=(1-\mathrm{p})=0,5$

$\mathrm{B}=$ Kesalahan diperkirakan berinterval range tidak lebih dari $10 \%$.

Adapun perhitungan sample untuk penelitian ini adalah sebagai berikut ini:

$$
\begin{aligned}
n & =\frac{246 \cdot(0,5 \cdot 0,5)}{(246-1) \frac{10 \%^{2}}{4}+0,5 \cdot 0,5} \\
& =\frac{61,5}{0,8625} \\
& =71,30 \\
& =71 \text { Perusahaan (29\%) }
\end{aligned}
$$

Setelah jumlah sampel ditetapkan maka langkah selanjutnya adalah memilih sample dengan menggunakan metode proportional stratified random sampling. Metode ini dipilih karena unsur-unsur populasi yang bersifat heterogen yaitu terdiri dari bermacam-macam jenis industri. Dengan metode ini populasi yang digunakan akan diklasifikasikan menurut jenis industri. 


\section{HASIL DAN PEMBAHASAN}

Data yang diperoleh dari analisis deskriptif menunjukkan nilai tertinggi (maximum), nilai terendah (minimum), rata-rata (mean), dan standar deviasi dari setiap variabel yang diteliti yaitu Ukuran Perusahaan (UP), Profitabilitas (PR), Tipe Perusahaan (TP), Reputasi Auditor (RA), dan variabel dependen yaitu Internet Financial Reporting (IFR). Hasil analisis dapat dilihat pada tabel 1.1 dibawah ini.

Tabel 1.1 Deskripsi Data Penelitian

\begin{tabular}{lrrrrr}
\hline & N & Minimum & Maximum & Mean & Std. Deviation \\
\hline UP (X1) & 71 & 22,80 & 42,70 & 29,2690 & 2,76305 \\
PR (X2) & 71 &, 0002 & 5,44 &, 2623 &, 83873 \\
TP (X3) & 71 & 0 & 1 &, 51 &, 504 \\
RA (X4) & 71 & 0 & 1 &, 41 &, 495 \\
IFR (Y) & 71 & 0 & 1 &, 56 &, 499 \\
Valid N (listwise) & 71 & & & & \\
\hline
\end{tabular}

Berdasarkan Tabel dapat disimpulkan bahwa Ukuran Perusahaan (UP) perusahaan non Efek Indonesia tahun 2016 memiliki nilai terendah 22,80 (22,8\%), nilai tertinggi 42,70 (42,7\%), dan rata-rata sebesar 29, 2690 (29,26\%) dengan nilai standar deviasi sebesar 2,76305 (2,76\%). Emiten yang memiliki nilai UP minimum adalah PT. Ricky Putra Globalindo Tbk (RICY) pada tahun 2016 sedangkan emiten yang memiliki nilai UP maksimum adalah PT. Midi Utama Indonesia Tbk (MIDI). Variabel Profitabilitas (PR) perusahaan non keuangan yang terdaftar di Bursa Efek Indonesia tahun 2016 memiliki nilai terendah $.0002(0,02 \%)$, nilai tertinggi $5,44(54,4 \%)$, dan rata-rata sebesar .2623 $(26,23 \%)$ dan nilai standar deviasi sebesar .83873 (83,8\%).

Adapun emiten yang menduduki nilai PR minimum adalah PT. Aneka Tambang Tbk (ANTM) dan emiten dengan nilai PR tertinggi adalah PT. Matahari Department Store Tbk (MPPA). Tipe Perusahaan (TP) perusahaan non keuangan yang terdaftar di Bursa Efek Indonesia tahun 2016 memiliki nilai terendah 0, nilai tertinggi 1 dan rata-rata sebesar .51 dan nilai standar deviasi sebesar .504. Reputasi Auditor (RP) perusahaan non keuangan yang terdaftar di Bursa Efek Indonesia tahun 2016 memiliki nilai terendah 0, nilai tertinggi 1 dan rata-rata sebesar .41 dan nilai standar deviasi sebesar .495 . Internet Financial Reporting (IFR) perusahaan non keuangan yang terdaftar di Bursa Efek Indonesia tahun 2016 memiliki nilai terendah 0, nilai tertinggi 1 dan rata-rata sebesar .56 dan nilai standar deviasi sebesar .499 .

Tabel 1.2 tabulasi silang variabel tipe perusahaan dibawah ini menunjukkan bahwa terdapat $40(56,3 \%)$ dari 71 perusahaan yang termasuk dalam jenis perusahaan non manufaktur dimana $26(74,3 \%)$ diantaranya menerapkan IFR dan $9(25,7 \%)$ perusahaan cenderung tidak menerapkan IFR. Sedangkan untuk $31(43,7 \%)$ perusahaan yang termasuk dalam jenis perusahaan manufaktur diketahui ada 14 perusahaan atau $(38,9 \%)$ yang menerapkan IFR sementara $22(15,7 \%)$ perusahaan lagi tidak menerapkan IFR. 
Tabel 1.2 Tabulasi Silang Variabel Tipe Perusahaan

\begin{tabular}{|c|c|c|c|c|c|}
\hline & & & \multicolumn{2}{|c|}{ IFR (Y) } & \multirow[b]{2}{*}{ Total } \\
\hline & & & Non IFR & IFR & \\
\hline \multirow{4}{*}{$\begin{array}{l}\mathrm{TP} \\
(\mathrm{X} 3)\end{array}$} & Non & Count & 9 & 26 & 35 \\
\hline & Manufaktur & $\begin{array}{l}\text { \% within TP } \\
\text { (X3) }\end{array}$ & $25,7 \%$ & $74,3 \%$ & $100,0 \%$ \\
\hline & Manufaktur & Count & 22 & 14 & 36 \\
\hline & & $\begin{array}{l}\% \text { within TP } \\
\text { (X3) }\end{array}$ & $61,1 \%$ & $38,9 \%$ & $100,0 \%$ \\
\hline \multirow[t]{2}{*}{ Total } & & Count & 31 & 40 & 71 \\
\hline & & $\begin{array}{l}\text { \% within TP } \\
(\mathrm{X} 3)\end{array}$ & $43,7 \%$ & $56,3 \%$ & $100,0 \%$ \\
\hline
\end{tabular}

Selanjutnya tabel 1.4 tabulasi silang variabel reputasi dibawah menunjukkan bahwa terdapat 22 (52,4\%) perusahaan yang menggunakan jasa KAP Non Big Four yang tidak menerapkan IFR dan $20(47,6 \%)$ perusahaan yang menggunakan jasa KAP Non Big Fouryang menerapkan IFR. Sedangkan perusahaan yang menggunakan jasa KAP Big Four yang tidak menerapkan IFR berjumlah $9(31,0 \%)$.

Tabel 1.3 Tabulasi Silang Variabel reputasi

\begin{tabular}{|c|c|c|c|c|c|}
\hline & & \multicolumn{4}{|c|}{ IFR (Y) } \\
\hline & & & Non IFR & IFR & Total \\
\hline RA & Non Big & Count & 22 & 20 & 42 \\
\hline \multirow[t]{3}{*}{ (X4) } & Four & $\begin{array}{l}\text { \% within RA } \\
\text { (X4) }\end{array}$ & $52,4 \%$ & $47,6 \%$ & $100,0 \%$ \\
\hline & Big Four & Count & 9 & 20 & 29 \\
\hline & & $\begin{array}{l}\% \text { within RA } \\
(\mathrm{X} 4)\end{array}$ & $31,0 \%$ & $69,0 \%$ & $100,0 \%$ \\
\hline \multirow[t]{2}{*}{ Total } & & Count & 31 & 40 & 71 \\
\hline & & $\begin{array}{l}\text { \% within RA } \\
(\mathrm{X} 4)\end{array}$ & $43,7 \%$ & $56,3 \%$ & $100,0 \%$ \\
\hline
\end{tabular}

\section{Uji Hipotesis}

Untuk menguji hipotesis maka dalam penelitian ini menggunakan model prediksi dengan regresi logistik untuk menguji pengaruh dari variabel Ukuran Perusahaan, Profitabilitas, Tipe Perusahaan dan Reputasi Auditorterhadap probabilitas perusahaan yang menerapkan IFR(Internet Financial Reporting) dengan perusahaan yang tidak menerapkan IFR (Non Internet Financial Reporting).

\section{Hasil Uji Kelayakan Model Regresi (Hosmer and Lemeshow Test)}

Untuk menilai kelayakan model regresi dapat dilihat melalui uji Hosmer danLemeshow atau dapat disebut sebagai Goodness of fit tes. 
Tabel 1.4 Hosmer and Lemeshow Test

\begin{tabular}{llll}
\hline Step & Chi-square & Df & Sig. \\
\hline 1 & 12,426 & 8 &, 133 \\
\hline
\end{tabular}

Hasil output SPSS menunjukkan bahwa nilai Hosmer and Lemeshow Test sebesar 12,426 dan signifikansi pada 0,133 oleh karena nilai ini berada di atas 0,05 maka model dikatakan fit dan model dapat diterima.

\section{Hasil Uji Keseluruhan Model (Overall Model Fit)}

Untuk menilai layak tidaknya keseluruhan model maka dapat dilihat melalui overal model fit test yang dapat dilihat dari nilai -2 log likelihood (-2LL). Pada tabel 5.4. terlihat bahwa nilai blok pertama (Block Number $=0$ ) adalah sebesar 97,83 dan dari Tabel 5.5 terlihat bahwa nilai blok kedua (Block Number $=1$ ) adalah sebesar 68,494. Hal ini berarti hanya konstanta saja tanpa adanya variabel bebas adalh 97,83 turun menjadi 68,494 . Model ini menunjukkan adanya penurunan Overall Model Fit pada -2 Loglikelihood block number $=0$ ke -2 Loglikelihood block number $=1$ sebesar 29,336. Penurunan likelihood menunjukkan secara keseluruhan model regresi logistik yang digunakan merupakan model yang baik, dimana menurut Ghozali (2013), penurunan nilai -2 log likelihood menunjukkan bahwa model penelitian ini dinyatakan model fit. Artinya, penurunan likelihood ini menunjukkan model regresi yang lebih baik atau dengan kata lain model yang dihipotesiskan fit dengan data.

Tabel 1.5 Tabel overall Model Fit

\begin{tabular}{|c|c|c|c|c|}
\hline Step & $\begin{array}{c}-2 \text { Log } \\
\text { likelihood }\end{array}$ & $\begin{array}{c}\text { Cox \& Snell } \\
\text { R Square }\end{array}$ & $\begin{array}{c}\text { Nagelkerke } \\
\text { R Square }\end{array}$ & \\
\hline 1 & $68,494^{\mathrm{a}}$ & ,333 &, 553 & \\
\hline \multicolumn{5}{|c|}{$\begin{array}{l}\text { a. Estimation terminated at iteration } \\
\text { number } 9 \text { because parameter estimates } \\
\text { changed by less than }, 001 \text {. }\end{array}$} \\
\hline \multicolumn{5}{|c|}{ Tabel 1.6 Iteration History } \\
\hline \multicolumn{2}{|c|}{ Iteration } & $-2 \log$ & likelihood & $\begin{array}{c}\text { Coefficients } \\
\text { Constant }\end{array}$ \\
\hline \multirow[t]{3}{*}{ Ste } & $\begin{array}{ll}0 & 1\end{array}$ & & 7,283 &, 254 \\
\hline & 2 & & 7,283 & ,255 \\
\hline & 3 & & 7,283 &, 255 \\
\hline
\end{tabular}


Tabel 1.7 Iteration History ${ }^{\mathrm{a}, \mathrm{b}, \mathrm{c}, \mathrm{d}}$

\begin{tabular}{|c|c|c|c|c|c|c|c|}
\hline \multirow[b]{2}{*}{ Iteration } & & \multirow[b]{2}{*}{-2 Log likelihood } & \multicolumn{5}{|c|}{ Coefficients } \\
\hline & & & Constant & $\mathrm{X} 1$ & $\mathrm{X} 2$ & X3 & $\mathrm{X} 4$ \\
\hline \multirow[t]{9}{*}{ Step 1} & 1 & 78,398 & 3,892 &,- 115 &, 521 & $-1,575$ & ,922 \\
\hline & 2 & 75,666 & 4,578 &,- 136 & 1,159 & $-1,887$ & 1,125 \\
\hline & 3 & 72,163 & 4,313 &,- 134 & 2,961 & $-1,905$ & 1,152 \\
\hline & 4 & 69,882 & 4,028 &,- 130 & 5,563 & $-1,966$ & 1,204 \\
\hline & 5 & 68,736 & 3,846 &,- 130 & 8,810 & $-2,021$ & 1,247 \\
\hline & 6 & 68,499 & 3,798 &,- 132 & 11,089 & $-2,076$ & 1,284 \\
\hline & 7 & 68,494 & 3,802 &,- 133 & 11,474 & $-2,088$ & 1,291 \\
\hline & 8 & 68,494 & 3,802 &,- 133 & 11,482 & $-2,089$ & 1,291 \\
\hline & 9 & 68,494 & 3,802 &,- 133 & 11,482 & $-2,089$ & 1,291 \\
\hline
\end{tabular}

Table 1.8 Variables in the Equation

\begin{tabular}{|c|c|c|c|c|c|c|c|}
\hline & & $\mathrm{B}$ & S.E. & Wald & Df & Sig. & $\operatorname{Exp}(B)$ \\
\hline \multirow[t]{5}{*}{ Step 1a } & $\mathrm{X} 1$ & $-0,133$ & 0,122 & 1,191 & 1 & 0,275 & 0,875 \\
\hline & $\mathrm{X} 2$ & 11,482 & 5,727 & 4,019 & 1 & 0,045 & 96932,05 \\
\hline & X3 & $-2,089$ & 0,665 & 9,866 & 1 & 0,002 & 0,124 \\
\hline & $\mathrm{X} 4$ & 1,291 & 0,621 & 4,325 & 1 & 0,038 & 3,638 \\
\hline & Constant & 3,802 & 3,712 & 1,049 & 1 & 0,306 & 44,79 \\
\hline
\end{tabular}

a. Variable(s) entered on step 1: X1, X2, X3, X4.

Omnibus Test of Model Coefficient (Uji Simultan-G)

Tabel 1.9 Omnibus Tests of Model Coefficients

\begin{tabular}{|c|c|c|c|c|}
\hline & & $\begin{array}{c}\text { Chi- } \\
\text { square }\end{array}$ & $\mathrm{df}$ & Sig. \\
\hline \multirow[t]{3}{*}{ Step 1} & Step & 28,789 & 4 & 0 \\
\hline & \multirow{2}{*}{$\begin{array}{l}\text { Block } \\
\text { Model }\end{array}$} & 28,789 & 4 & 0 \\
\hline & & 28,789 & 4 & 0 \\
\hline
\end{tabular}

Dari tabel diatas diketahui bahwa nilai Chi-square sebesar 28,794 dengan degree of freedom adalah 4 . Adapun tingkat signifikansi sebesar 0,000 yang nilainya lebih kecil dari 0,05, maka H1 diterima, sehingga dapat disimpulkan bahwa nilai signifikansi 5\% variabel ukuran perusahaan, profitabilitas, tipe perusahaan, dan reputasi auditor secara simultan berpengaruh terhadap Internet Financial Reporting pada perusahaan non keuangan yang terdaftar di Bursa Efek Indonesia Periode 2016.

\section{Pengujian Individual / Pengujian Koefisien Regresi (Uji Parsial)}

Berdasarkan hasil pengujian secara parsial (uji t) yang dapat dilihat pada tabel 5.8, hasil empiris memperlihatkan dari 4 (empat) variabel independen yang diteliti hanya 3 (tiga) variabel yang berpengaruh signifikan terhadap IFR, yaitu variabel profitabilitas, tipe perusahaan, reputasi auditor. Hal ini dapat dilihat dari nilai probabilitas statistik lebih kecil dari $\alpha=0,05$. Sedangkan variabel ukuran perusahaan tidak mempengaruhi IFR pada perusahaan non keuangan yang terdaftar di Bursa Efek Indonesia Tahun 2016.Berdasarkan hasil uji koefisien regresi, dapat diperoleh persamaan regresi logistik menjadi sbb :

$$
\operatorname{Ln} \frac{p}{1-p}=3,802-, 133 \mathrm{UP}+11,482 \mathrm{PR}-2,089 \mathrm{TP}+1,291 \mathrm{RA}
$$




\section{SIMPULAN}

Dari hasil estimasi yang diperoleh, secara parsial variabel profitabilitas, tipe perusahaan, dan reputasi auditor berpengaruh dan signifikan terhadap Internet Financial Reporting (IFR)pada perusahaan non keuangan yang terdaftar di Bursa Efek Indonesia tahun 2016, sedangkan variabel ukuran perusahaan tidak berpengaruh. Secara simultan variabel ukuran perusahaan, profitabilitas, tipe perusahaan, dan reputasi auditor berpengaruh dan signifikan terhadap Internet Financial Reporting (IFR)pada perusahaan non keuangan yang terdaftar di Bursa Efek Indonesia tahun 2016. Peluang perusahaan non keuangan yang menerapkan Internet Financial Reporting (IFR) lebih besar dari perusahaan-perusahaan yang tidak menerapkan IFR, dimana jumlah yang menerapkan sebesar 40 perusahaan sementara yang tidak sebesar 31 perusahaan

\section{DAFTAR PUSTAKA}

Aly, D., Simon, J. and Hussairey, K. (2010), “ Determinants of corporate internet reporting: evidence from Egypt”, Managerial Auditing Journal, Vol. 25, No. 2, pp. 182-202.

Azizah, N. F., \& Hutagalung, D. D. (2018). Aplikasi 'MICE Indonesia'Pada Smartphone Sebagai Alat Promosi MICE Indonesia Kepada Dunia. Epigram, 15(1).

Budi, Triton Prawira. (2006). SPSS 13.0 Terapan, Riset Statistik Parametrik, Yogyakarta: ANDI.

Craven and Marston (1999), "Financial reporting on the internet by leading UK companies", The Europaean Accounting Review, Vol. 18, No.2, pp. 321-330.

Debreceny, R., G.L. Gray and A. Rahman, "The Determinants of Internet Financial Reporting,"Journal of Accounting and Public Policy 21, (2002), pp. 371-394.

Ettredge, M., V.J. Richardson and S. Scholz, "The Presentation of Financial Information at Corporate Web Sites," International Journal of Accounting Information Systems 2, (2001), pp. 149-168.

Fitriani, 2001.Signifikansi Perbedaan Tingkat Kelengkapan Pengungkapan Wajib dan Sukarela pada Laporan Keuangan Perusahaan Publik yang Terdaftar di Bursa Efek Jakarta.Makalah dipresentasikan pada Simposium Nasional Akuntansi IV.

Ghozali, Imam dan M. Mansur, "Analisis Faktor-Faktor yang Mempengaruhi Tingkat Underpriced Di Bursa Efek Jakarta," Jurnal Bisnis dan Akuntansi Vol.4, April (2002), pp. 74-88.

Ghozali, Imam, 2011. Aplikasi Analisis Multivariate dengan Program IBM SPSS 19, Edisi Kelima, Badan Penerbit Universitas Diponegoro, Semarang.

Gujarati, Damodar. 2003. Ekonometrika Dasar. Jakarta; Erlangga.

Hadi, N. dan A. Sabeni, "Analysis of Factors Affecting The Extent of Voluntary Disclosure in The Annual Report of Public Company Firms in Jakarta Stock Exchange," Jurnal Maksi Vol.1, Agustus (2002), pp. 39-61.

Hanny dan Chariri, 2006, 'Analisis faktor-faktor yang mempengaruhi pelaporan keuangan melalui internet', Jurnal Riset Akuntansi Indonesia vol.6, (2012), pp. 41-51.

Hartanto, H. (2018). Strategi Perusahaan Multinasional Di Era Globalisasi (Studi Kasus Glokalisasi Dalam Ekspansi “Indomie" Ke Pasar Timur Tengah Dan Afrika). Jurnal Sosial dan Humaniora, 3(5).

Hasugian, P. S. (2018). Perancangan Website Sebagai Media Promosi Dan Informasi. Journal Of Informatic Pelita Nusantara, 3(1).

Keumala, (2013) "Analisis faktor-faktor yang mempengaruhi pelaporan keuangan melalui internet”, Jurnal Maksi vol.1, pp. 39-61.

Prastiwi, P. I., Astuti, D. S. P., \& Harimurti, F. (2019). Pengaruh ukuran perusahaan, leverages, sistem pengendalian internal, dan reputasi auditor terhadap audit delay dengan audit tenure sebagai variabel moderasi. ejurnal.unisri.ac.id

Rohmah, A. N., \& Priantinah, D. (2018). Pengaruh Ukuran Perusahaan, Umur Perusahaan, Leverage Keuangan, Good Corporate Governance Terhadap Kualitas Laporan Keuangan. Jurnal Profita: Kajian Ilmu Akuntansi, 6(2).

Wolk, H., M.G. Tearney and J.L. Dodd (2000).Accounting Theory: A Conceptual and Institutional Approach.South Western College Publishing.

Xiao, J. Z., H. Yang and C. W. Chow, "The Determinants and Characteristics of Voluntary Internet Based Disclosures by Listed Chinese Companies," Journal of Accounting and PublicPolicy 23, (2004), pp. 191-225.

Zuhrotun, (2006) 'Keinformatifan Laba di Pasar Obligasi dan Saham: Uji Liquidation Option Hypothesis”, eMarketer .co.id, www.idx.co.id. 